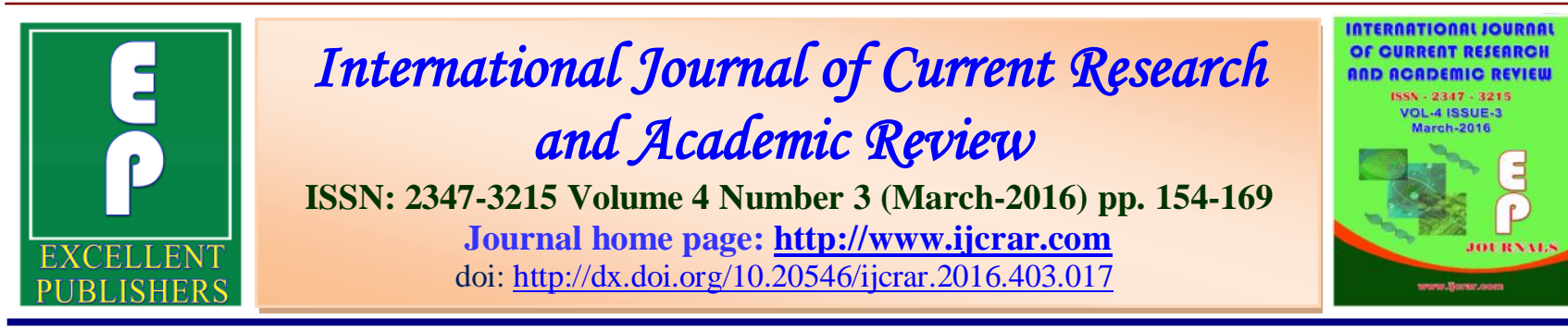

\title{
Floristic Composition and Structure of a Deciduous Dry Forest from Southern Ecuador: Diversity and Aboveground Carbon Accumulation
}

Vinicio Carrión-Paladines $^{1 *}$ and Roberto García-Ruiz ${ }^{2}$

${ }^{1}$ Department of Food and Agricultural Sciences, Universidad Técnica Particular de Loja, San Cayetano Alto s/n C.P. 1101 608, Loja, Ecuador

${ }^{2}$ Department of Animal Biology, Vegetable Biology and Ecology, Universidad de Jaén (Spain)

*Corresponding author

\section{\begin{tabular}{l|l} 
KEYWORDS & A B S T R A C T
\end{tabular}}

Composition,

Diversity,

Abundance,

Dominance,

Categories, Carbon

reserve.

Semi deciduous dry forests in southern Ecuador are valued internationally for
their conservation significance, and important locally as a source of timber
for agroforestry. Data with which to evaluate the compatibility of these
interests is currently lacking. In permanent sample plots (PSP) established
according to a simple random design, 12 species were found, representing 12
genera and 11 botanical families. The ecological analysis was performed by
determining the basal area, height, density, frequency, dominance, IVI and
FIV. The most diverse families are Burseraceae, Bignoniaceae and
Caesalpiniaceae. However, the species with the highest IVI are: Bursera
graveolens, Tabebuia chrysantha and Caesalpinia glabrata. The basal area of
the species studied was $11.4 \mathrm{~m}^{2}$ ha $^{-1}$ with a volume of $66.35 \mathrm{~m}^{3} \mathrm{ha}^{-1}$. The size
class distribution for most tree/species highlighted the absence of the
large/order individuals, which reflect the disturbance of the forest.
Aboveground biomass was estimated and the carbon found was $68.06 \mathrm{Mg}$ ha
1 , with an amount of $33.04 \mathrm{Mg}^{-1}$ of carbon stored, results that are within
normal ranges for the seasonally dry tropical forests. This study provides
important baseline information on the species composition of the forest as
well as the conservation status of species.

\section{Introduction}

Dry Forests (DF) are the most utilized, perturbed, fragmented and less conserved of the planet among the forests (Murphy \& Lugo, 1986; Stoner \& Sánchez -Azofeifa, 2009; Quesada et al, 2009). Despite the fact that DF represent $42 \%$ of global vegetable formations (Hartshorn, 1983; Gentry, 1990), there is scant information about the natural regeneration of this valuable ecosystem (Vieira \& Scariot, 2006; Bertoncini \& Ribeiro, 2008; Esquivel et al., 2008; Stoner \& Sánchez -Azofeifa, 2009). DF are 
characterized by having regular events of dryness that define the temporal regimes and magnitude of the majority of their ecological processes (Murphy \& Lugo, 1995; Maass \& Burgos, 2011). Annual precipitation is lower than $1.600 \mathrm{~mm}$ and, the dry season, with a precipitation lower than $100 \mathrm{~mm}$, lasts up to six months (Pennington et al., 2000). Therefore, ecological processes in DF show a marked seasonal behavior. For example, the net primary productivity is less than that in the tropical rainforests because it only occurs during the rainy period (Aguirre et al., 2006). These forests are also characterised for having a lower height and basal area than typical tropical humid forests (Linares-Palomino 2004a, 2004b; Aguirre et al., 2006). Compared with all the other biomes, the DFs have experienced the greatest loss of habitat and conversion of the land due to the settlement and increase of human population, poverty, forest exploitation, and agricultural expansion (Novick et al., 2003; Kolb \& Diekmann, 2004; Stork, 2010). In addition, natural regeneration is seriously negatively affected as a result of the introduction of exotic species and the over pasturing of species such as goats (Capra hircus), cows (Bos taurus Linnaeus) and the pastures of wild animals such as Melopsittacus undulatus (Shaw), Odocoileus virginianus (Zimmermann), and Sylvilagus floridanus (J. A. Allen) that feed on young plants (Coblentz, 1978; Schofield, 1989; Campbell \& Donlan, 2005; Peacok \& Sherman, 2010; García et al., 2012). Kharkwal et al. (2005) posit that this process accelerates the loss of species and therefore could lead, at the medium to long term, to the collapse of the eco-system.

Therefore the maintenance of DFs are likewise important for protecting the environment, as well as for the rural economy. In fact, many people have integrated them into their daily lives and use them to take advantage of their (natural) resources. Woody forest species, which are as economically important, such as Tabebuia chrysantha and Loxopterigium huasango and fuelwood can also benefit rural communities. Useful plants such as Myroxylum peruiferum, Piscidia carthagenensis, Cordia lutea, Erythrina smithiana, Bursera graveolens [Kunth Triana \& Planchon] from which bark, latex, and resins can be extracted, are further examples of benefits to local farming communities and agricultural workers (Aguirre et al., 2006; Espinosa et al., 2012; Aguirre-Mendoza, et al., 2013). However, in such forests, the rate of exploitation surpasses other possibilities of natural recovery (Aguirre et al., 2006). Despite this anthropegenic pressure, many DFs have been declared areas of special protection and conservation, that is, compared with other ecosystems (Hoekstra et al., 2005; Janzen, 1988; Miles et al., 2006; Portillo-Quintero \& Sánchez-Azofeifa, 2010).

In Latin America, DFs are frequently studied in the fields of ecology, floristic diversity, economics, and in the assessment of the impacts of deforestation (Murphy \& Lugo. 1986; Mendes et al., 2012; LópezBarrera et al., 2014). In Ecuador, however, they are characterized by their structure, composition, diversity, endemism, functions, and by the usage of forest species that comprise it (Cerón, 1993, 1996; Hernández \& Josse, 1997; Madsen et al., 2001, Aguirre et al., 2006; Espinosa et al., 2012). The DFs from the south-west of Ecuador are thus considered to be fragile, i.e. seeing that they contain many endemic species that are under threat with regards to their original composition (Aguirre et al., 2006; Espinosa et al., 2012). In these forests, ethno-botanical studies have been carried out on the usage of trees and plants 
of various medicinal and edible species (Van den Eynden et al., 1999; Béjar et al., 2001; 2003; Sánchez et al., 2006).

It has been observed that some researchers have implemented quantitative floristic inventories based on the establishment of Permanent Parcels (PSP), with the aim of characterizing the vegetation of DFs. In these sample areas, their structure, composition and diversity have all been documented (Parthasarathy, 2001; Sagar et al., 2003). Finally, there has been a growing interest in the documentation of the dynamics of the DFs in the long-term via the establishment and monitoring of PSP. These forest inventories constitute an invaluable research base for various aspects of tropical ecology, while at the same time providing crucial information about their conservation and management (Ayyappan \& Parthasarathy, 1999).

The main objective of this research paper is to describe the structure of vegetation throughout the evaluation of its composition, diversity, and content of biomass and forest carbon in a moderately perturbed DF of the south-west of Loja, Ecuador. In addition, it aims to provide information that will help to understand the current DF situation, the ecological implications and the conservation efforts that are required for eco-systems.

\section{Materials and Methods}

\section{Site of the Study Area}

The research was carried out in the province of Loja, in the region of Zapotillo, which is located in the south-west of Ecuador $\left(4^{\circ} 16^{\prime}\right.$ $44^{\prime \prime}$ south and $80^{\circ} 17^{\prime} 44^{\prime \prime}$ west, and between $4^{\circ} 21^{\prime} 27^{\prime \prime}$ south and $80^{\circ} 19^{\prime} 53^{\prime \prime}$ west; Figure 1). The altitude varies from 230 to $328 \mathrm{~m}$ a.s.l. The annual average temperature is $25^{\circ} \mathrm{C}$, with an average annual precipitation rate of between 400 to $600 \mathrm{~mm}$. (Sánchez et al., 2006). The experimental site corresponds to a tropical dry forest (DF -T) (Holdridge, 1967; Cañadas, 1983), forming part of the Tumbesian region, which contains a great diversity of endemic species from different taxonomic groups that are constantly under the threat of extinction because of human activities (Best \& Kessler, 1995; Leal-Pinedo \& Linares-Palomino, 2005; Mittermeier et al., 2005; Sánchez et al., 2006; Aguirre et al., 2006; LinaresPalomino et al., 2010; 2011; Espinosa et al., 2012; López-Barrera et al., 2014).

\section{Sampling Description}

In the research area, 20 PSP were installed by means of simple random design (De Souza \& Ferreira, 2004; Tarrasón et al., 2010). The dimension of each PSP corresponds to $400 \mathrm{~m}^{2}(20 \mathrm{~m} \mathrm{x} 20 \mathrm{~m})$, covering a total sample area of $8000 \mathrm{~m}^{2}$. Altitude and the UTM coordinates were recorded. The number of species and individuals were recorded in each PSP during the rainy season (March and April). Leaves, flowers and fruit samples were collected and trees were identified at species level.

\section{Basal Area and Aboveground Biomass and Carbon Calculation}

In this study, the diameter was measured at breast height $(\mathrm{DBH}) \geq 5 \mathrm{~cm}$ (Aguirre \& Delgado, 2005; Imaña et al., 2010), and the sizes and total measurement of the branch stub (m) were recorded using the Haga altimeter. The diametric classes were determined at the following intervals: $(1)<$ $0.1 \mathrm{~m}$; (2) $0.11-0.2 \mathrm{~m}$; (3) $0.21-0.3 \mathrm{~m}$; (4) $0.31-0.4 \mathrm{~m}$; (5) $0.41-0.5 \mathrm{~m}$ and (6) > 0,5 $\mathrm{m}$ (LaFrankie et al., 2006). The average basal area by diametric size was obtained with the following equation: $\mathrm{AB}=\pi / 4 *$ 
DAP $^{2}$ (Pardé \& Bouchon, 1994; Philip, 1994). The average volume (V) was calculated according to: $\mathrm{V}=\mathrm{Ht} * \mathrm{AB} * f$ where $\mathrm{Ht}$ is total height, $\mathrm{AB}$ basal area and $f$ form factor (Pardé \& Bouchon, 1994; Philip, 1994; Orozco \& Brumér, 2002). Values were transformed to hectare according to:

$\mathrm{AB}\left(\mathrm{m}^{2} \mathrm{ha}^{-1}\right)=\mathrm{Na} \mathrm{ha}{ }^{-1} * \mathrm{AB}$, for basal area and

$\mathrm{V}\left(\mathrm{m}^{3} \mathrm{ha}^{-1}\right)=\mathrm{Na} \mathrm{ha}^{-1} * \mathrm{~V}$, for tree volume

Where:

$\mathrm{Na} \mathrm{ha}^{-1}=$ Number of trees per hectare.

With this information, we calculated the quantity of biomass by diametric class and by $\mathrm{ha}^{-1}$, utilizing the formula proposed by Brown, (1997) and Dávalos et al. (2008):

$\mathrm{B}=\mathrm{VT} * p i * \mathrm{FEB}$

Where:

$\mathrm{B}=$ Biomass

VT $=$ Volume ha ${ }^{-1}$

pi $\quad=$ Specific weight of wood $\left(\mathrm{g} \mathrm{cm}^{-3}\right)$

FEB $=$ Expansion Factor of Biomass

$p i$ was assumed to be the weighted average per ecoregion such as that recommended by Brown \& Lugo, (1992) and Brown, (1997). In this study, the wood densities were used according to the studies performed by Zanne et al. (2009), that is, for the eco-region of South America (tropical) and whose value is $0,641 \mathrm{gr} \mathrm{cm}^{-3}$. The value used for the FEB corresponds to 1.6, according to Dixon, (1995) and Andrade \& Ibrahim (2003).

The carbon content was calculated using the following formula (Brown, 1997; Dávalos et al. 2008).

$\mathrm{C}=\mathrm{B} * \mathrm{fc}$

Where:
$\mathrm{C}=$ stored carbon by trees $\left(\mathrm{TC} \mathrm{ha}^{-1}\right)$

$\mathrm{B}=$ biomass (weight) of trees

$\mathrm{fc}=$ fraction of Carbon in the biomass (a calculation of 0.5 IPCC, 1994; Figueroa et al., 2005; Díaz et al., 2007).

For this parameter, we carried out a regression analysis and a linear correlation with the average volume data by diametric class, and calculated biomass. We used Version 15.0 of the SPSS statistical software program (SPSS Inc, Chicago), and considered as an independent variable, the different classes of DBH. For the dependent variable, we considered the $\mathrm{kg}$ of tree biomass. The calculation of the biomass $\left(\mathrm{ha}^{-}\right.$ ${ }^{1}$ ) and $\mathrm{C}\left(\mathrm{ha}^{-1}\right)$ by diametric class was done by calculating the number of individuals per hectare. In this case, we only considered the quantity of carbon stored in the aerial part of the biomass. The total biomass of the trees was converted into carbon storage values $(C$ $\left.\mathrm{ha}^{-1}\right)$ in accordance with the studies carried out by Dávalos et al. (2008).

\section{The Structural Analysis of the Forest}

The structural analysis of the forest was carried out based on the ecological indices such as benchmarks for Relative Abundance (RA), Relative Dominance (RD), Importance Value Index (IVI), Family Importance Value (FIV), and Relative Diversity (RD) according to Curtis \& Cottam (1962), Mori et al. (1983) and Cerón, (1993).

\section{Results and Discussion}

\section{Floristic Composition}

Trees of the dry forest PSP were comprised of 12 species belonging to11 families and 12 genera (Table 1). There are on average 299 individuals per $\mathrm{ha}^{-1}$, most of which are concentrated in the diametric classes: $0.1-$ 
0.2 (161 individuals) and $0.21-0.3 \mathrm{~m}$ (64 individuals) (Figure 2). The highest density was recorded for Tabebuia chrysantha and Caesalpinia glabrata, with 116 ha $^{-1}$ and 69 $\mathrm{ha}^{-1}$ (Figure 3) individuals, respectively.

\section{Dasometric Parameters}

Figure 4 shows the highest basal area for the diametric classes, $0.21-0.3$ and $0.31-0.4$ $\mathrm{m}$. The individuals that are greater than 0.50 $\mathrm{m}$ in diameter correspond to Bursera graveolens, C. glabrata and Eriotheca ruizii. These reach a diameter of $0.54 ; 0.59$ and 0.59 , respectively, that is, with a basal area of $1,028 \mathrm{~m}^{2} \mathrm{ha}^{-1}$. The highest volumes were found in classes $0.21-0.3$ and $0.31-0.4 \mathrm{~m}$, with 16 and $23.6 \mathrm{~m}^{3} \mathrm{ha}^{-1}$ (Figure 5). 59.5\% of individuals are located in classes with a height of 5-10 m (Figure 6). Conversely, less than $15.7 \%$ of trees belong to classes greater than $10 \mathrm{~m}$, implying that the forest is comprised of small trees that are less than 10 $\mathrm{m}$ in height. There is only one individual of B. graveolens, which reaches $16 \mathrm{~m}$.

\section{Biomass and Forest Carbon}

The dispersion in the observed values of tree biomass is shown in figure 7. Upon adjusting the equation for determining the biomass function of the normal diameter, the coefficient of determination $\left(\mathrm{r}^{2}=0,93 ; \mathrm{P}\right.$ $>0,05$ ) was highly significant. The summary of the model indicates that the DBH (m), influences $93 \%$ of the weight $(\mathrm{kg})$ of the species. In other words, there is an increase in the diameter and the age of the species and a greater quantity of biomass $(\mathrm{kg})$.

The values of biomass and carbon that were obtained by diametric classes and hectare calculation are shown in figure 8. In DF, there is an approximate quantity of 68.06 $\mathrm{Mg} \mathrm{ha}{ }^{-1}$ of accumulated biomass, and an approximate quantity of $33.04 \mathrm{Mg} \mathrm{ha}^{-1}$ of carbon. The diametric class $0.31-0.4 \mathrm{~m}$ accumulates the greatest quantity of biomass $\left(24193.9 \mathrm{~kg}\right.$ aboveground biomass ha ${ }^{-}$ ${ }^{1}$ ), and carbon (12097.0 $\mathrm{kg} \mathrm{C} \mathrm{ha}^{-1}$ ), followed by the diametric class $0.21-0.3 \mathrm{~m}$ (16409.6 $\mathrm{kg}$ aboveground biomass $\mathrm{ha}^{-1}$ and 80204.8 $\mathrm{kg} \mathrm{C} \mathrm{ha-1).}$

\section{Ecological Parameters}

The most abundant species is $T$. chrysantha (38.9\%) followed by C. glabrata (23\%), B. graveolens $(19.2 \%)$ and $P$. carthagenensis $(10.5 \%)$. Abundance of the remaining species was lower than 8 individuals per hectare and less than $1.3 \%$ of relative abundance. Trees in PSPs were dominated by $B$. graveolens and $C$. glabrata, with $41.7 \%$ and $21.7 \%$ respectively, followed by the species and values of $T$. chrysantha $\mathrm{y}$ Piscidia carthagenensis - with $9.9 \%$ and $9.7 \%$, respectively (Table 2). The species with greater IVI were $B$. graveolens, $T$. chrysantha and C. glabrata - with 60.9, 48.8, and 44.7, respectively, whereas $P$. carthagenensis showed an intermediate value (20.2). E. ruizii showed a value of 13.0 IVI. IVI values for the 7 remaining species was lower than 4.2.

On the other hand, the values of the Family Importance Value (FIV) are shown in Table 2. The highest values are for the Burseraceae family (69.3); Bignoniaceae (57.1) and Caesalpinaceae (53.0). The other families have values that are less than 28.5 FIV.

There are 11 families with 12 species (Table 1). These values were lower than those typically reported in other DF located on the Pacific coast in the north-west of South America. Indeed, in the DF of the Colombian forests of Tierra Bomba, Galerazamba and Tasajero it Has Been Recorded Between 26 and 56 families, 55 to 
67 families and 30 families with 60 species respectively (Gentry, 1995; Mendoza, 1999; Carrillo-Fajardo et al., 2007). In DF of the north of Peru, García-Villacorta (2009) found 75 species belonging to 25 families in Tarapoto. In the north-eastern biosphere, Leal-Pinedo \& Linares-Palomino (2005) reported 34 families with 85 species on average in a single hectare. Similarly, in some DFs of Ecuador a greater quantity of families was reported. In the Nature Reserve "La Ceiba", which is very close to our study zone, 37 families were found with 49 species. What is more, for the DF in the province of Loja, it is estimated that there are on average 29 families with 58 species (Aguirre et al., 2013; Aguirre et al., 2014). With regard to tree density of the DF that were examined, there are 299 individuals (per ha ${ }^{-1}$ ). Similarly to species quantification, these values are lower than others that have been registered for dry zones of Ecuador. For example, for the deciduous DF forest El Pechiche, 538 individuals ha ${ }^{-1}$ were reported (Josse, 1997). Similarly, Madsen (2001) reported 422 individuals (per ha ${ }^{-1}$ ) for the vegetation on Isla Puná. For the DF protected areas in the province of Loja, Klitgaard et al. (1999) found 670 individuals per $\mathrm{ha}^{-1}$ in the DF in Puyango (Aguirre et al., 2014), as well as
1,057 individuals per $\mathrm{ha}^{-1}$ in the Reserve called "La Ceiba". The reason there are fewer few species in the DF in Loja compared with the protected areas is that they are constantly subjected to very severe anthropogenic pressure (Aguirre et al. 2014). This includes fire and over-pasturing, indeed, fire is used as a technique to establish new crops (Lewis, 1994; Anderson, 1999; Fulé et al., 2011), which is an activity that is carried out in the province, i.e. on the banks of the rivers, leading to a continuous landscape fragmentation. The main consequences of the fragmentation are loss of habitat, change in the configuration of habitat, increases in the extinction of species, loss of bio-diversity, and increase in the vulnerability of local human populations (Mooney \& Hobbs, 2000; Pimm \& Raven, 2000; Jules \& Shahani, 2003; Steffen et al., 2003). Notwithstanding, over-pasturing and the trampling on the undergrowth by shegoats (Capra hircus L.), goat cattle (Bos taurus) and the harvesting of non-timber forest products (NTFP), despite not being directly related to the transformation of forest cover, reduces the diversity of species and limits the processes of regeneration (Stern et al., 2002; Ticktin. 2004; Carrión et al., 2007; Chynoweth et al., 2013).

\section{Table.1 Forest Species that make up the Tropical Dry Forest of South Western Ecuador}

\begin{tabular}{cc}
\hline Family & Scientific name \\
\hline ANACARDIACEAE & Loxopterygium huasango \\
BIGNOCIACEAE & Tabebuia chrysantha \\
BIXACEAE & Cochlospermum vitifolium \\
BOMBACACEAE & Eriotheca ruizii \\
BURCERACEAE & Bursera graveolens \\
CACTACEAE & Cereus diffusus \\
CAESALPINACEAE & Caesalpinia glabrata \\
FABACEAE & Geoffroea spinosa \\
FABACEAE & Piscidia carthagenensis \\
POLYGONACEAE & Coccoloba ruiziana \\
RHAMNACEAE & Ziziphus thyrsiflora \\
RUBIACEAE & Simira ecuadorensis \\
\hline
\end{tabular}


Int.J.Curr.Res.Aca.Rev.2016; 4(3): 154-169

Table.2 Ecological Parameters of Vegetation

\begin{tabular}{|c|c|c|c|c|c|c|}
\hline Family & Scientific name & $\begin{array}{c}\text { Tree } \\
\text { density } \\
\left(h^{-1}\right)\end{array}$ & $\begin{array}{c}\text { Relative } \\
\text { abundance (\%) }\end{array}$ & $\begin{array}{c}\text { Relative } \\
\text { dominance } \\
(\%)\end{array}$ & IVI & FIV \\
\hline ANACARDIACEAE & Loxopterygium huasango & 4 & 1,3 & 2,9 & 4,2 & 12,5 \\
\hline BIGNOCIACEAE & Tabebuia chrysantha & 116 & 38,9 & 9,9 & 48,8 & 57,1 \\
\hline BIXACEAE & $\begin{array}{l}\text { Cochlospermum } \\
\text { vitifolium }\end{array}$ & 4 & 1,3 & 2,9 & 4,2 & 12,5 \\
\hline BOMBACACEAE & Eriotheca ruizii & 8 & 2,5 & 10,1 & 13,0 & 20,9 \\
\hline BURCERACEAE & Bursera graveolens & 58 & 19,2 & 41,7 & 60,9 & 69,3 \\
\hline CACTACEAE & Cereus diffusus & 1 & 0,4 & 0,1 & 0,5 & 8,8 \\
\hline CAESALPINACEAE & Caesalpinia glabrata & 69 & 23,0 & 21,7 & 44,7 & 53,0 \\
\hline FABACEAE & Geoffroea spinosa & 1 & 0,4 & 0,7 & 1,1 & 17,8 \\
\hline FABACEAE & Piscidia carthagenensis & 31 & 10,5 & 9,7 & 20,2 & 17,8 \\
\hline POLYGONACEAE & Coccoloba ruiziana & 5 & 1,7 & 0,4 & 2,1 & 28,5 \\
\hline RHAMNACEAE & Ziziphus thyrsiflora & 1 & 0,4 & 0,3 & 0,7 & 10,4 \\
\hline RUBIACEAE & Simira ecuadorensis & 1 & 0,4 & 0,1 & 0,5 & 9,1 \\
\hline
\end{tabular}

Figure.1 Geographic Location of the Study Area

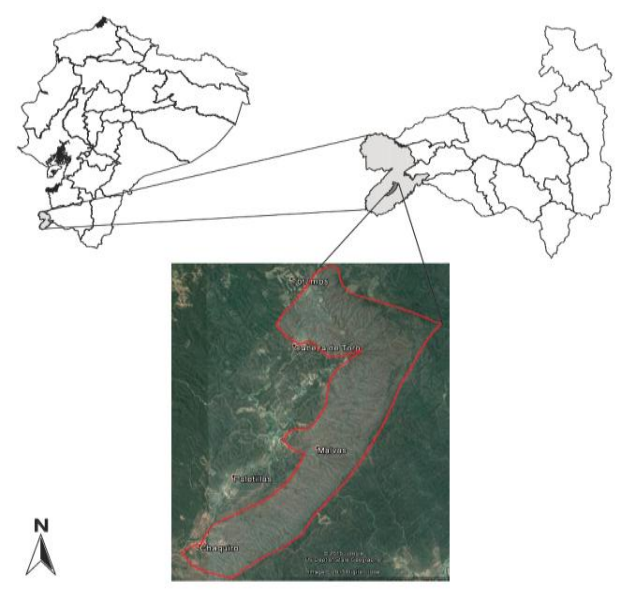

Figure.2 Number of Individuals Per Hectare

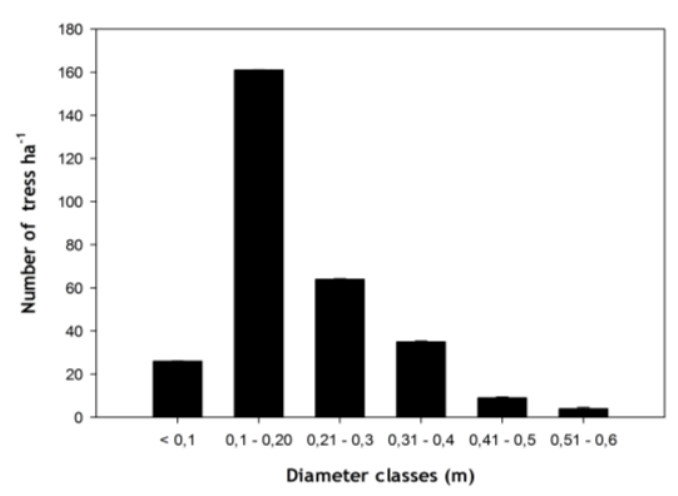


Figure.3 Number of Individuals Per Hectare and Per Species

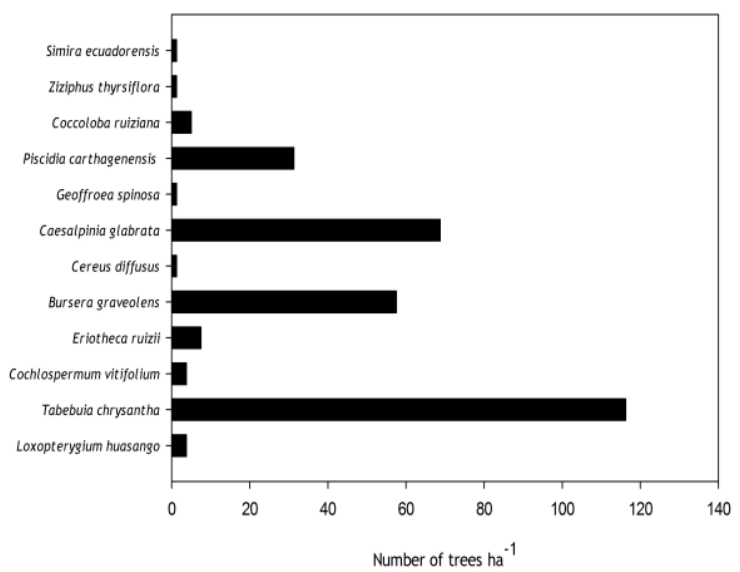

Figure.4 Density of Trees and Basal Area of Tropical Dry Forest

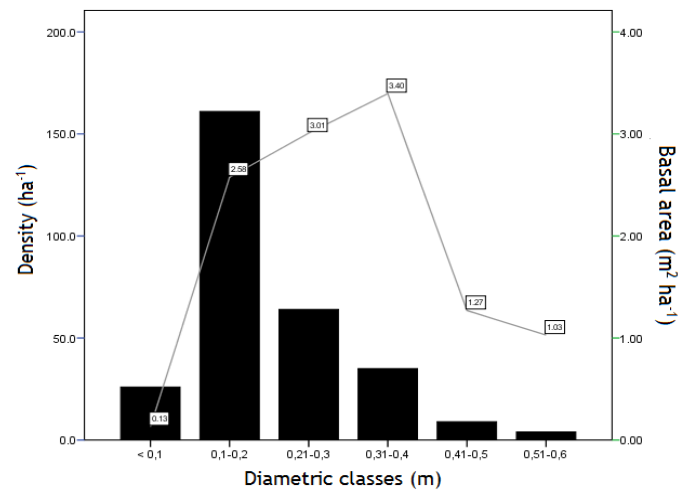

Figure.5 Density of Trees and Timber Volume in the Dry Tropical Forest

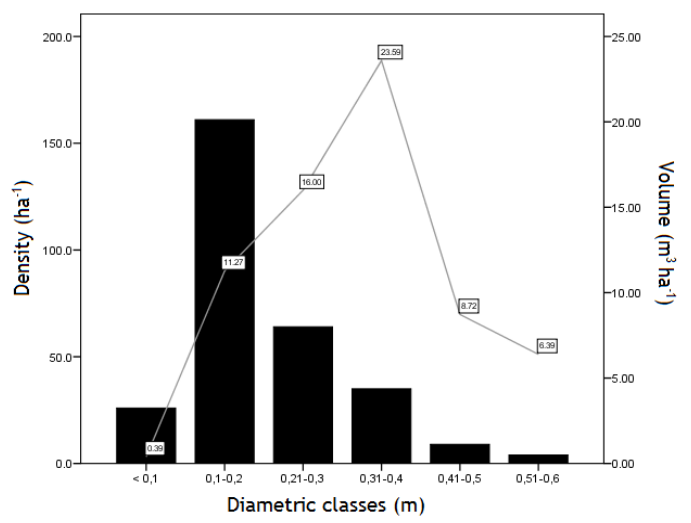


Int.J.Curr.Res.Aca.Rev.2016; 4(3): 154-169

Figure.6 Distribution of Trees by Height Classes

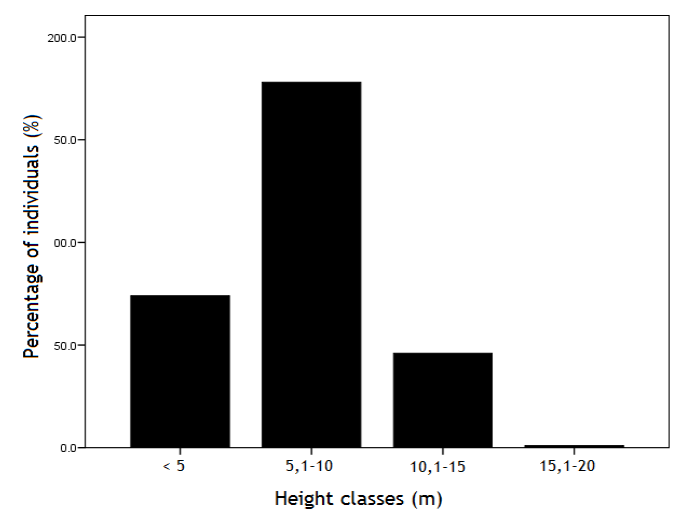

Figure.7 Dispersion of Observed Values and Exponential Regression Line Data Generated with Biomass Content

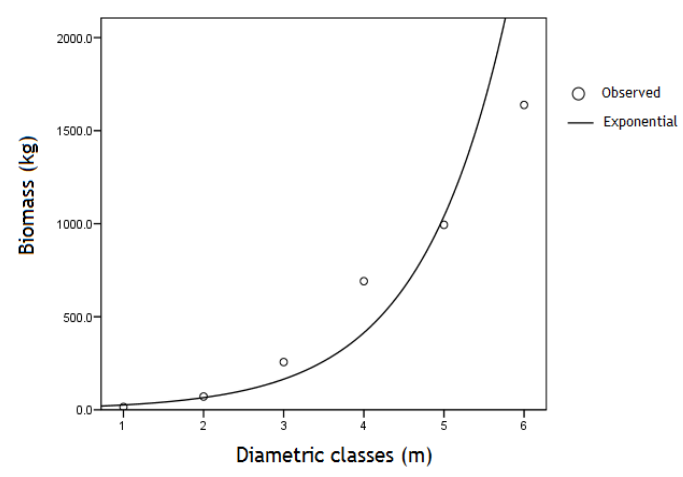

Figure.8 Biomass and Carbon Content in the Dry Tropical Forest, According to Diameter Classes

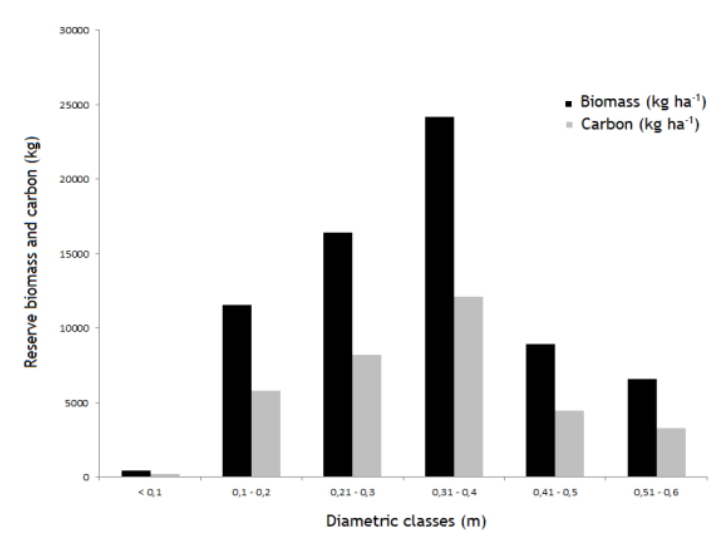

Despite the fact that the DFs tree abundance was relatively low compared to other DFs, basal area $\left(11.4 \mathrm{~m}^{2} \mathrm{ha}^{-1}\right)$ and volume $(66.4$ $\mathrm{m}^{3} \mathrm{ha}^{-1}$ ) were higher than that of others DF.
For instance, a basal area and volume of about $1 \mathrm{~m}^{2} \mathrm{ha}^{-1}$ and $13 \mathrm{~m}^{3} \mathrm{ha}^{-1}$ has been reported in a DF of Ghana (Appiah, 2012). However, values were lower than that 
reported for others, for example in India's Bhadra Wildlife Sanctuary. In this DF basal area was calculated to be $18.09 \mathrm{~m}^{2} \mathrm{ha}^{-1}$ (Krishnamurthy et al., 2010). In some parts of the Americas, DF with much greater basal area have been found. For instance, Gillespie et al. (2000) reported values of $22.03 \mathrm{~m}^{2} \mathrm{ha}^{-1}$ for some DF of Central America, and White \& Hood (2004) reported $20.7 \mathrm{~m}^{2} \mathrm{ha}^{-1}$ in the Peninsula of Yucatán. Castro et al. (2005) reported in Nicaragua's Chacocente Wildlife reserve a, basal area $\left(15.62 \mathrm{~m}^{2} \mathrm{ha}^{-1}\right)$ slightly higher than that found in this study. In the DF in Loja, Aguirre et al. (2014) found in protected areas such as the Reserve "La Ceiba", basal area and volume $\left(26.73 \mathrm{~m}^{2}\right.$ ha ${ }^{1}$ and $169.41 \mathrm{~m}^{3} \mathrm{ha}^{-1}$ ) between two and three times higher than that reported in this study. For this reason, it is likely that values of this study correspond to that of a perturbed DF. Indeed, tree distribution in our DF was considered to be very "sparse" (Dry forest project, 1998). On the other hand, according to Aguirre et al. (2013), the diametric structures of the DF in the province of Loja are characterized by the concentration of individuals in the first classes; these results coincide with that of our study. Higher tree density corresponded to that of classes 0.1 0.2 and $0.21-0.3 \mathrm{~m}$. This proves that most trees were thin, likely as a consequence of selective felling practices without appropriate planning. With regard to the height of the trees, our results are similar to others registered in DF from the province. Thus, Klitgaard et al. (1999) in their floristic and structural studies in the El Tundo and Puyango forests, found that the canopy reaches heights between ranges $5-10$, or above.

In the DF, accumulated aboveground biomass accounted for about $68,06 \mathrm{Mg} \mathrm{ha}^{-1}$ and $33.04 \mathrm{Mg} \mathrm{C} \mathrm{ha}{ }^{-1}$. These figures were found to be within the range reported by
Becknell et al. (2012), who found that in the seasonally dry tropical forests, the quantity of biomass varies from 39 to $334 \mathrm{Mg} \mathrm{ha}^{-1}$ (or 19.5 to $167.0 \mathrm{Mg} \mathrm{C} \mathrm{ha}^{-1}$ ). However, the actual figure is lower in relation to other DF of America. Vargas et al. (2008) found, in the forest reserve El Eden in Mexico, values which doubled that of our study $(143.9 \mathrm{Mg}$ $\mathrm{ha}^{-1}$ or $71.9 \mathrm{Mg} \mathrm{C} \mathrm{ha}^{-1}$ ). The differences in the amount of aboveground biomass and carbon stock among forests is highly related to the annual precipitation in the DF (Becknell et al., 2012). These variations reflect the age, diameter, and height of the forest components, as well as the density of the population of each layer (Alegre et al., 2000; Martel \& Cairampoma, 2012).

Tabebuia chrysantha (119 ind. ha ${ }^{-1}$ with $\mathrm{AB}$ $\left.=1.6 \mathrm{~m}^{2} \mathrm{ha}^{-1}\right)$ and Caesalpinia glabrata $(70$ ind. $\mathrm{ha}^{-1}$ with $\mathrm{AB}=2.4 \mathrm{~m}^{2} \mathrm{ha}^{-1}$ ) are ecologically more important for their higher density levels. However, those species such as Bursera graveolens, despite having less density (i.e. 58 ind. $\mathrm{ha}^{-1}$ ), are more predominant because of their greater basal area $\left(4,4 \mathrm{~m}^{2} \mathrm{ha}^{-1}\right)$. Compared with the DF from the North of Peru and the province of Loja, some researchers have reported Ceiba trichastandra, Simira ecuadorensis, Tabebuia chrysantha, Eriotheca ruizii and Terminalia valverdeae as the most important species (Klitgaard et al., 1999; Linares \& Ponce, 2005; Linares et al., 2010; Aguirre et al., 2013). However, only the species Tabebuia chrysantha was present in our study. Moreover, for protected forests such as the reserve "La Ceiba", the species with greater IVI correspond to Simira ecuadorensis (17.49\%), Tabebuia chrysantha (14,21\%), Ceiba trichistandra $(11,54 \%)$ and Cordia macrantha (10,52\%). This could be due to the environmental and physiographic conditions, and the levels of anthropogenic alteration that the DF are subjected to, which not only influence 
certain species, but also fluctuate between abundant and dominant types (Aguirre et al., 2014).

\section{Conclusion}

The floristic wealth of DF is characterized by 12 species that exist within a range of 12 genera and 11 botanical families. The most diverse families in this study are the following: Burseraceae, Bignoniaceae and Caesalpiniaceae. However, the species with a greater IVI are: $B$. graveolens, $T$. chrysantha and $C$. glabrata. The basal area of the studied species was $11.4 \mathrm{~m}^{2} \mathrm{ha}^{-1}$, whereas the volume was $66.35 \mathrm{~m}^{3} \mathrm{ha}^{-1}$. The species that provided the greatest contribution to the basal area production and tree volume were $B$. graveolens, $C$. glabrata and Eriotheca ruizii. Most of the trees examined in this study can be grouped into the first three diametric classes. These diametric classes are determined by an inverted " $J$ " trend, indicating that the forest is perturbed. The mean quantity of aboveground biomass was about $68.06 \mathrm{Mg}$ $\mathrm{ha}^{-1}$ and a pre-established quantity of 33.04 $\mathrm{Mg} \mathrm{ha}{ }^{-1}$ of stored carbon. This quantity is found within normal ranges for seasonally dry tropical forests.

\section{Acknowledgement}

I wish to extend my thanks to the Secretaria de Ciencia y Tecnología del Ecuador (the Secretariat of Science and Technology of Ecuador), and the Department of Food and Agricultural Sciences at the Universidad Técnica Particular de Loja. We thank Belind Ashe and David Duncan for comments and suggestion on the manuscript.

\section{References}

Aguirre, Zh., Delgado, T. 2005. Vegetación de los bosques secos de cerro Negro-
Cazaderos, occidente de la provincia de Loja In: Biodiversidad en los bosques secos de la zona de Cerro Negro-Cazaderos, occidente de la provincia de Loja: un reporte de las evaluaciones ecológicas $\mathrm{y}$ socioeconómicas rápidas. Vázquez, M.A., J.F. Freire y L. Suárez (Eds.). EcoCiencia, MAE y Proyecto Bosque Seco. Quito. pp. 5-8.

Aguirre, Zh., Kvist, L., Sánchez, O. 2006. Bosques secos en Ecuador y su diversidad. Botánica Económica de los Andes Centrales, pp. 162-187.

Aguirre-Mendoza, Zh., BetancourtFigueras, Y., Greada-López, G., JasenGonzáles, H. 2013. Composición florística, estructura de los bosques secos y su gestión para el desarrollo de la provincia de Loja, Ecuador. Revista científica Avances. 15(2): 130-146.

Aguirre, Zh., Ruri, D., Betancourt, Y., Greada, G. 2014. Composición florística, estructura y endemismo en una parcela permanente de bosque seco en Zapotillo, provincia de Loja, Ecuador. Arnaldoa, 21(1): 165-178.

Anderson, M. 1999. The fire, pruning, and coppice management of temperate ecosystems for basketry material by California Indian tribes. Human Ecol., 27: 79-113.

Andrade, H., Ibrahim, M. 2003. ¿Cómo monitorear el secuestro de carbono en los sistemas silvopastoriles?. Agroforestería en las Américas, 10: 39-40.

Appia, M. 2012. Tree population inventory, diversity and degradation analysis of a tropical dry deciduous forest in Afram Plains, Ghana. Forest Ecol. Management, 295: 145-154.

Ayyappan, N., Parthasarathy, N. 1999. Biodiversity inventory of trees in a large scale permanent plot of tropical evergreen forest at Varagalaiar, 
Anamalai, Western Ghats, India. Biodiversity and Conservation, 8: 1533-1554.

Becknell, J., Kissing, L., Powers, J. 2012. Aboveground biomass in mature and secondary seasonally dry tropical forests: A literature review and global synthesis. Forest Ecol. Management, 276: 88-95.

Béjar, E., Bussmann, R., Roa, C., Sharon, D. 2001. Herbs of southern Ecuador. A field guide to the medicinal plants of Vilcabamba. LH Press, Spring Valley, California. pp. 350.

Bertoncini, A., Ribeiro, R. 2008. Forest restoration in an indigenous land considering a forest remnant influence Avaí, Sao Paulo State, Brasil. Forest Ecol. Management, 255: 513-521.

Best, B., Kessler, M. 2005. Biodiversity and Conservation in Tumbesian Ecuador and Peru. Cambridge, UK. Birdlife International.

Brown, S. 1997. Estimating biomass and biomass change of tropical forests: a primer. FAO Forestry Paper, 134.

Brown, S., Lugo, A. 1992. Aboveground biomass estimates for tropical moist forests of the Brazilian Amazon. Interciencia, 17(1): 8-18.

Campbell, K., Donlan, C. 2005. Feral goat eradications on islands. Conservation Biol., 19: 1362-1374.

Cañadas, L., 1983. El Mapa Bioclimático y Ecológico del Ecuador. MAGPRONAREG. Quito - Ecuador. Editores asociados, $210 \mathrm{p}$.

Carrillo-Fajardo, M., Rivera-Díaz, O., Sánchez-Montaño, R. 2007. Caracterización florística y estructural del bosque seco tropical del cerro tasajero, san José de Cúcuta (norte de Santander), Colombia. Actual Biol., 29(86): 55-73.

Carrión, V., Donlan, J., Campbell, K., Lavoie, Ch., Cruz, F. 2007. Feral donkey (Equus asinus) eradications in the Galápagos. Biodiversity and Conservation, 16: 437-445.

Castro, G., Nygård, R., Gonzales, B., Christer P. 2005. Stand dynamics and basal area change in a tropical dry forest reserve in Nicaragua. Forest Ecol. Management, 208: 63-75.

Cerón, C. 1993. Estudio preliminar de plantas útiles del Parque Nacional Machalilla. Hombre y Ambiente. Ediciones Abya-Yala, 25: 73-130.

Cerón, C. 1996. Diversidad, Especies Vegetales y usos en la Reserva Ecológica Manglares-Churute, Provincia del Guayas, Ecuador. Geográfica, 36: 1-92.

Coblentz, B. 1978. The effects of feral goats (Capra hircus) on island ecosystems. Biological Conservation, 13: 279-286.

Chynoweth, M., Litton, C., Lepczyk, Ch., Hess, S., Cordell S. 2013. Biology and Impacts of Pacific Island Invasive Species. 9. Capra hircus, the Feral Goat (Mammalia: Bovidae). Pacific Sci., 67(2): 141-156.

Dávalos, R., Rodrigues, M., Pinillos-Cueto, E. 2008. Almacenamiento de carbono. En: Manson, R., Hernández-Ortiz, V., Gallina, S., \& Mehltreter, K (Eds.). Agroecosistemas cafetaleros de Veracruz. Biodiversidad, manejo y conservación. México.

Dixon, R. 1995. Agroforestry systems: Sources or sinks of greenhouse gases? Agroforestry Sys., 31: 99-116.

Espinosa, C., De la Cruz, M., Escudero, A. 2012. Bosques tropicales secos de la región Pacífico Ecuatorial: diversidad, estructura, funcionamiento e implicaciones para la conservación. Ecosistemas, 21(1-2): 167-179.

Esquivel, M., Harvey, C., Casanoves, F., Skarpe, Ch. 2008. Effects of pasture management on the natural 
regeneration of neotropical tres. $J$. Appl. Ecol., 45: 371-380.

Fulé, P., Ramos-Gómez, M., CortézMontaño, C., Miller, A. 2011. Fire regime in a Mexican forest under indigenous resource management. Ecol. Appl., 21(3): 764-775.

García, R., Celaya, R., García, U., Osoro, K. 2012. Goat grazing, its interactions with other herbivores and biodiversity conservation issues. Small Ruminant Res., 107: 49-64.

García-Villacorta, R. 2009. Diversidad, composición y estructura de un hábitat altamente amenazado: los bosques estacionalmente secos de Tarapoto, perú. Rev. Peru. Biol., 16(1): 81-92.

Gentry, A. 1990. Floristic Similarities and differences between southern Central America and upper and central Amazonia. pp. 141-160. In: A.H. Gentry (ed.) Four Neo tropical Rainforests. Yale University Press, New Haven, CT.

Gentry, A. 1995. Diversity and floristic composition of neotropical dry forests. En: Bullock, S.H., Mooney, H.A., Medina, E. (eds.). Seasonally Dry Tropical Forests. pp. Pages 146-194. Cambridge University Press, Cambridge, UK.

Gillespie, T., Grijalva, A., Farris, Ch. 2000. Diversity, composition, and structure of tropical dry forests in Central America. Pl. Ecol., (147): 37-47.

Hartshorn, G. 1983. Plants: introduction. pp. 118-157. In: D.H. Janzen (ed.) Costa Rican natural history. University of Chicago Press, Chicago.

Hernández, C., Josse, C. 1997. Plantas silvestres comestibles del Parque Nacional Machalilla. Hombre y Ambiente, Abya-Yala, Quito, 40: 178.

Hoekstra, J., Boucher, T., Ricketts, T., Roberts, C. 2005. Confronting a biome crisis: global disparities of habitat loss and protection. Ecol. Lett., (8): 23-29.

Holdridge, L. 1967. Life Zone Ecol., Tropical Science Center, San Jose, Costa Rica.

Imaña, J., Antunes, O., Rainier, C. 2010. Estructura diamétrica de un fragmento del bosque tropical seco de la región del eco-museo del cerrado, Brasil. Colombia Forestal, 14(1): 23-30.

IPCC. 1994. The Supplementary Report to the IPPCC Scientific Assessment. Cambridge University Press, Cambridge. 205 p.

Janzen, D. 1988. Tropical dry forests. The most endangered major tropical ecosystem. In: Wilson, E.O. (Ed.), Biodiversity. National Academy Press, Washington., pp. 130-137.

Josse, C. 1997. Dinámica de un bosque seco semideciduo y secundario en el oeste del Ecuador. En: Valencia $\mathrm{R}$ y $\mathrm{H}$. Balslev (Eds.). Estudios sobre diversidad y ecología de plantas. Memorias del 11 Congreso Ecuatoriano de Botánica. Pontificia Universidad Católica del Ecuador. Quito, pp. 241-254.

Jules. E., Shahani, P. 2003. A broader ecological context to habitat fragmentation: why matrix habitat is more important then we thought. $J$. Vegetation Sci., (14): 459-64.

Kharkwal, G., Mehrotra, P., Pangtey, Y. 2005. Comparative studies on species richness, diversity and composition of oak forests in Nainital district, Uttarachal. Curr. Sci., (89): 668-672.

Klitgaard, B., Lozano, P., Aguirre, Z., Merino, B., Aguirre, N., Delgado, T., Elizalde, F. 1999. Composición florística y estructural del bosque petrificado de Puyango. Estudios Botánicos en el sur del Ecuador. Universidad de Loja, Herbario Loja, (3): 25-49. 
Kolb, A., Diekmann, M. 2004. Effects of environment, habitat configuration and forest continuity on the distribution of forest plant species. J. Vegetation Sci., 15(2): 199-208.

Krishnamurthy, Y., Prakasha, H., Nanda, A., Krishnappa, M., Dattaraja, H., Suresh, H. 2010. Vegetation structure and floristic composition of a tropical dry deciduous forest in Bhadra Wildlife Sanctuary, Karnataka, India. Trop. Ecol., 51(2): 235-246.

Leal-Pinedo, J., Linares-Palomino, R. 2005. Los bosques secos de la reserva de biósfera del noroeste (Perú): Diversidad arbórea y estado de conservación. Caldasia, 27(2): 195211.

Linares-Palomino, R. 2004. Los bosques tropicales estacionalmente secos: I. El concepto de los bosques secos en el Perú. Arnaldoa, 11(1): 85-102.

Linares-Palomino, R. 2004. Los bosques tropicales estacionalmente secos: II. Fitogeografía y Composición Florística. Arnaldoa, 11(1): 103-138.

Linares-Palomino, R., Ponce, S. 2005. Tree community patterns in seasonally dry tropical forests in the Cerros de Amotape Cordillera, Tumbes, Peru.

Forest Ecol. Management, (209): 261272.

Linares-Palomino, R., Kvist, L.P., AguirreMendoza, Z., Gonzales-Inca, C. 2010. Diversity and endemism of woody plant species in the Equatorial Pacific seasonally dry forests. Biodiversity and Conservation, (19): 169-185.

Linares-Palomino, R., Oliveira-Filho, A.T., Pennington, R. 2011. Neotropical Seasonally Dry Forests: Diversity, Endemism and Biogeography of Woody Plants. En: Dirzo, R., Mooney, H., Ceballos, G., Young, H. (eds.). Seasonally Dry Tropical Forests: Ecol.
Conservation, pp. 3-21. Island Press. Washington, DC 20009, USA.

López-Barrera, F., Manson, R., Landgrave, R. 2014. Identifying deforestation attractors and patterns of fragmentation forseasonally dry tropical forest in central Veracruz, Mexico. Land Use Policy, (41): 274-283.

Madsen, J.E., Mix, R., Balslev, H. 2001. Flora of Puná Island. Plant resources on a Neotropical island. Aarhus University Press, Aarhus. 289 p.

Maass, M., Burgos, A. 2011. Water Dynamics at the Ecosystem Level in Seasonally Dry Tropical Forests. In: Dirzo, R., Mooney, H., Ceballos, G., Young, H. (eds.). Seasonally Dry Tropical Forests: Ecol. Conservation, pp. 141-156.

Martel, C., Cairampoma, L. 2012. Cuantificación del carbono almacenado en formaciones vegetales amazónicas en "cicra", Madre de Dios (Perú). Ecología Aplicada, 11(2).

Miles, L., Newton, A.C., Defries, R.S., Ravilious, C., May, I., Blyth, S., Kapos, V., Gordon, J. 2006. A global overview of the conservation status of tropical dry forests. J. Biogeog., (33): 491-505.

Mittermeier, R.A., Gil, P.R., Hoffman, M., Pilgrim, J., Brooks, T., Mittermeier, J., Lamoreux, C., Da Fonseca, G.A.B. 2005. Hotspots revisited: Earth's biologically richest and most endangered terrestrial ecoregions. pp. 431. CEMEX, México D.C. México.

Mori, S., Boom, B., De Carvalho, A., Dos Santos, T. 1983. Ecological importance of Myrtaceae in an eastern Brazilian wet forest forest. Biotropica, (15): 68-70.

Murphy, P.G., Lugo, A.E. 1986. Ecology of Tropical Dry Forest. Ann. Rev. Ecol. Evol. Systematics, 17: 67-88. 
Murphy, P.G., Lugo, A.E. 1995. Dry forests of Central America and the Caribbean. In: Bullock, S.H., Mooney, H.A., Medina, E. (eds.). Seasonally Dry Tropical Forests, pp. 9-34. Cambridge University Press, New York. USA.

Novick, R., Dick, Ch., Lemes, M., Navarro, C., Caccone, A., Bermingham, E. 2003. Genetic structure of Mesoamerican populations of Big-leaf mahogany (Swietenia macrophylla) inferred from microsatellite analysis. Mol. Ecol., 12: 2885-2893.

Orozco, L., Brumér, C. 2002. Inventarios forestales para bosques latifoliados en América central. CATIE, Turrialba, Costa Rica, 264 p.

Pardé, J., Bouchon, J. 1994. Dasométrica. 2da. Edición. Editorial Paraninfo. Madrid. España, 387 p.

Parthasarthy, N. 2001. Changes in forest composition and Structure in three sites of tropical Evergreen Forest around Sengaltheri, Western Ghats. Curr. Sci., 80: 389-393.

Peacok, C., Sherman, D. 2010. Sustainable goat production. Some global perspectives. Small Rumin. Res., (89): 78-80.

Pennington, R.T., Prado, D., Pendry, C. 2000. Neotropical seasonally dry forests and Quaternary vegetation changes. J. Biogeography, 27: 261273.

Philip, S. 1994. Measuring Trees and Forests. CAB International. Cambridge. UK. 310 p.

Portillo-Quintero, C.A., Sánchez-Azofeifa, G.A. 2010. Extent and conservation of tropical dry forests in the Americas. Bio. Cons., 143: 144-155.

Quesada, M., Stoner, K.E. 2004. Threats to the conservation of the tropical dry forest in Costa Rica. In: Frankie, G.W., Mata y, A., Vinson, S.B. (Eds.), Biodiversity Conservation in Costa
Rica: Learning the Lessons in a Seasonal Dry Forest. University of California Press, Berkeley, CA, pp. 266-280.

Quesada, M., Sanchez-Azofeifa, G., Alvarez-Añorve, M., Stoner, K., AvilaCabadilla, L., Calvo-Alvarado, J., Castillo, A., Espírito-santo, M., Fagundes, M., Fernades, G., Gamon, J., Lopezaraiza-Mikel, M., Lawrence, D., Cerdira, L., Powers, J., Neves, F., Rosas-Guerrero, V., Sayago, R.R., Sanchez-Montoya, G. 2009. Succession and management of tropical dry forests in the Americas: Review and new perspectives. Forest Ecol. Management, 258: 1014-1024.

Sagar, R., Raghubanshi, A.S., Singh, J. 2003. Tree species composition, dispersion and diversity along a disturbance gradient in a tropical forest region of India. Forest Ecol. Management, 186: 61-71.

Sánchez, O., Peter, L., Aguirre, Z. 2006. Bosques secos en Ecuador y sus plantas útiles. Botánica Económica de los Andes Centrales. 188-204.

Schofield, E. 1989. Effects of introduced plants and animals on island vegetation: examples from the Galapagos Archipelago, Ecuador. Conserv. Biol., 3: 227-238.

Stern, M., Quesada, M., Stoner, K. 2002. Changes in composition and structure of a tropical dry forest following intermittent Cattle grazing. Revista de Biol. Trop., 50: 3-4.

Stoner, K.E., Sánchez-Azofeifa, G.A. 2009. Ecology and regeneration of tropical dry forests in the Americas: implications for management. Forest Ecol. Management, 258(6): 903-906.

Stork, N. 2010. Reassessing extinction rates. Biodivers. Conserv., 19: 357-371.

Tarrasón, D., Urrutia, J., Ravera, F., Herrera, E., Andrés, P., Espelta, J. 2010. 
Conservation status of tropical dry forest remnants in Nicaragua: Do ecological indicators and social perception tally. Biodiversity Conservation, 19: 813-827.

Ticktin, T. 2004. The ecological implications of harvesting non-timber forest products. J. Appl. Ecol., 41: 1121.

Van den Eynden, V., Cueva, O., Cabrera, O. 1999. Plantas silvestres comestibles del sur del Ecuador - wild plants of southern Ecuador. Ediciones AbyaYala, Quito, 211 pp.

Van den Eynden, V., Cueva, O., Cabrera, O. 2003. Wild foods from Southern Ecuador. Economic Botany, 57: 576603.
Vargas, R., Allen, M., Allen, E. 2008. Biomass and carbon accumulation in a fire chronosequence of a seasonally dry tropical forest. Global Change Biol., 14: 109-124.

Vieira, D., Scariot, A. 2006. Principles of natural regeneration of Tropical Dry Forests for restoration. Restoration Ecol., 14(1): 11-20.

White, D., Hood, C. 2004. Vegetation patterns and environmental gradients in tropical dry forests of the northern Yucatan Peninsula. J. Vegetation Sci., 15: 151-160.

Zanne, A.E., Lopez-Gonzalez, G., Coomes, D.A., Ilic, J., Jansen, S., Lewis, S.L., Chave, J. 2009. Global wood density database.

\section{How to cite this article:}

Vinicio Carrion-Paladines and Roberto Garcia-Ruiz. 2016. Floristic Composition and Structure of a Deciduous Dry Forest from Southern Ecuador: Diversity and Aboveground Carbon Accumulation. Int.J.Curr.Res.Aca.Rev.4(3): 154-169. doi: http://dx.doi.org/10.20546/ijcrar.2016.403.017 